\title{
Genetic characterization of Coxiella burnetii in Amblyomma varigatum ticks from North-central Nigeria: public health importance
}

\author{
Ndudim Isaac Ogo ${ }^{1,2,3}$, Isabel Garcia Fernandez de Mera², Ruth Cecilia Galindo², \\ Oluyinka O Okubanjo ${ }^{3}$, Hajiya Mairo Inuwa ${ }^{4}$, Rowland I. S. Agbede ${ }^{3}$ and Jose de La Fuente ${ }^{2}$
}

1. Parasitology Division, National Veterinary Research Institute, Vom Plateau State, Nigeria; 2. Genomic group, Instituto de investigacion en recursos cingeticos (IREC) Cuidad Real, Spain; 3. Department of Parasitology and Entomology, Ahmadu Bello University, Zaria, Nigeria; 4. Department of Biochemistry, Ahmadu Bello University, Zaria, Nigeria.

Corresponding author: Ndudim Isaac Ogo, email: ogoendy@yahoo.com

Received: 10-06-2013, Revised: 05-08-2013, Accepted: 06-08-2013, Published online: 11-09-2013

doi: 10.14202/vetworld.2013.818-822 How to cite this article: Ogo NI, Fernández de Mera IG, Galindo RC, Okubanjo OO, Inuwa HM, Agbede RIS, de La Fuente J (2013) Genetic characterization of Coxiella burnetii in Amblyomma varigatum ticks from North-central Nigeria: public health importance, Veterinary World 6(10):818-822.

\begin{abstract}
Aim: The purpose of this pilot study was to genetically identify and characterize Coxiella burnetii from Amblyomma varigatum ticks collected on cattle in North central Nigeria.

Materials and Methods: A total of 40 partially fed ticks morphologically identified as adult A. variegatum ticks collected from cattle owned by Fulani pastoralists were evaluated for the presence of $C$. burnetii using PCR, cloning, and sequencing of the heat shock polypeptide gene $h t p B$.

Results: $C$. burnetii DNA was detected in $10(25 \%)$ of the ticks analyzed. Sequences for the $C$. burnetii gene htpB detected in our samples had $99-100 \%$ identity to all other $C$. burnetii that have been described and that are deposited in the GenBank database. Phylogenetic analysis using neighbor-joining method indicates the clustering of $C$. burnetii sequences from our study areas with those collected from Oyo state, South-western Nigeria and Spain.

Conclusion: This study shows a high infection rate of $C$. burnetii in A. variegatum ticks in the study areas. Phylogenetic inferences indicates that the strain of $C$. burnetii found in the North central states of Plateau and Nasarawa were same as those previously reported in the South western state of Oyo. The presence of this pathogen in naturally occurring A. variegatum tick populations could present an additional risk of Q-fever disease to humans, especially to the pastoralists that are closely associated with their animals and are easily exposed to tick bites. Therefore, further studies are needed to assess the competence of $A$. variegatum ticks as vectors of $C$. burnetii pathogens.
\end{abstract}

Keywords: Amblyomma variegatum, Coxiella burnetii, Nigeria, ticks, zoonosis

\section{I ntroduction}

Ticks are important vectors of various pathogenic agents that cause disease in humans and animals; some of these agents, such as Coxiella burnetii, are considered as emerging vector-borne pathogens as well as agents of bioterrorism [1]. C. burnetii is an obligate intracellular, gram-negative, gamma proteobacteria that infect and cause a worldwide zoonoses, Q fever, in humans and animals. Ticks act as reservoirs and responsible for the transmission of the pathogen to animals through their bite or fecal contamination [2, 3], and the major source of dissemination of the pathogen in the environment as a result of the high concentration of the pathogen in tick feces, saliva, and coxal fluid [4]. The infected domestic animals and pets through their milk, urine, feces, placental, and birth fluids are the main source of human infection $[5,6]$.

Although Inhalation of aerosolized $C$. burnetii organisms is the most important route of infection in humans, ingestion of raw milk or fresh dairy products can also cause infection [7]. Tick transmitted livestock

Copyright: The authors. This article is an open access article licensed under the terms of the Creative Commons Attribution License (http://creativecommons.org/licenses/by/2.0) which permits unrestricted use, distribution and reproduction in any medium provided the work is properly cited. coxiellosis have been associated with about 40 different tick species [6]. Even though a few of these tick species have been shown to be able to harbor and maintain $C$. burnetii, they are not the primary vectors of this pathogen for transmission to animal or humans since their role in the natural cycle of $C$. burnetii remains to be defined till date [4]. However, they are thought to acquire the pathogen during a blood meal on infected animals and may transmit the bacterium to other mammals during the next blood meal or by aerogenic spread of dried tick faecal excretions [3,8].

Amongst the tick genera that serve as reservoir for this pathogen, the genus Amblyomma seem to have a high prevalence and capacity to maintain the Coxiella and Coxiella-like symbionts as observed in studies involving $A$. americanum and $A$. cajennense $[9,10,11]$. The importance of this genus in the maintenance of tick-borne infectious pathogens and as vector of several zoonotic agents requires that species in the genus be properly studied.

In Nigeria, Amblyomma variegatum ticks are the largest, most abundant, and destructive on domestic animals, and pets, and are associated with the transmission of diseases such as anaplasmosis, babesiosis, heartwater, and rickettsiosis, which are of 


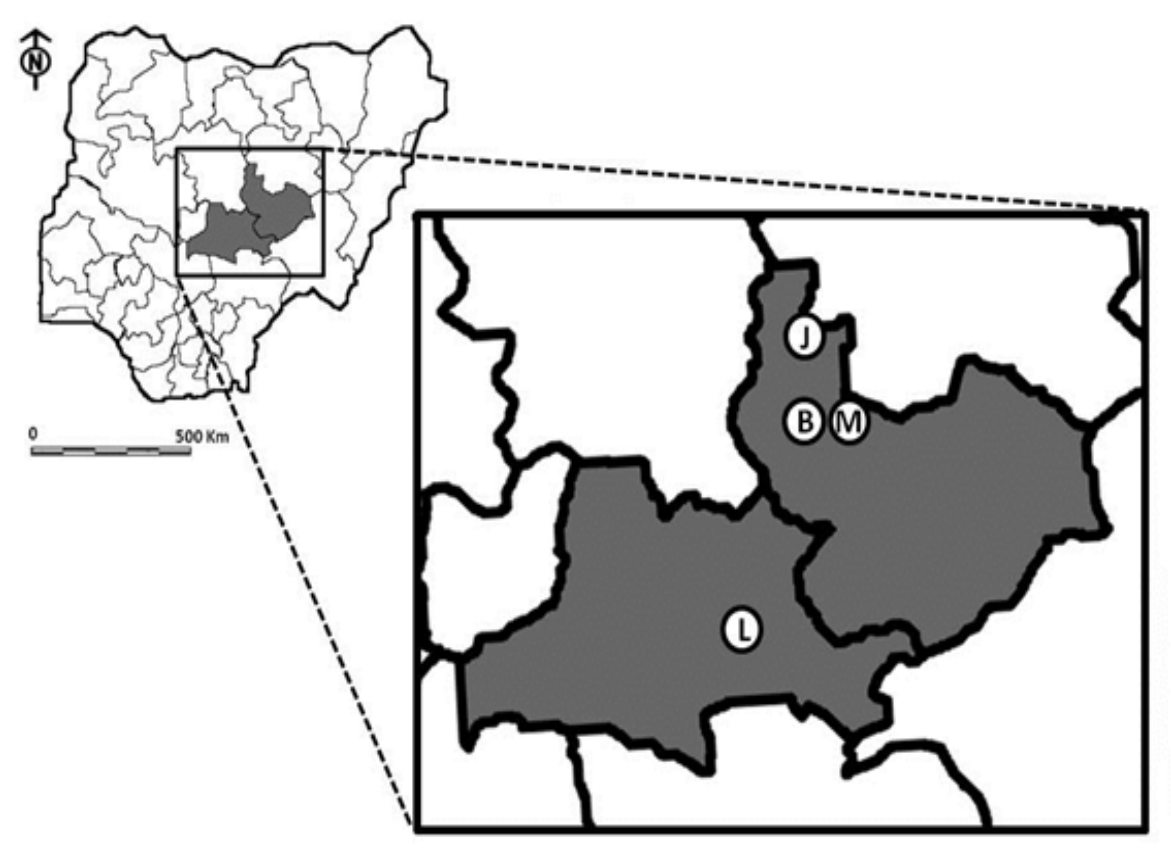

Figure-1. Map of Nigeria highlighting Nigerian regional borders. The amplification shows the Nigerian states (Plateau and Nassarawa) where sampling sites were located (J : J os; B: Barkin Ladi; M: Mangu; L: Lafia).

great importance to the I1vestock $[1 / 2,13]$. I he notoriety of this tick in terms of damage to the skin of animals during disease transmission and as pest has earned it the name "koti" ('dangerous tick') amongst the Fulani herdsmen of Nigeria, and thus is accorded much attention during acaricidal treatment and the routine hand de-ticking exercise [14].

Studies have shown that the collection of ticks from hosts or vegetation and analysis by genus-specific and/or species specific PCR is an efficient method for the assessment of tick-borne pathogens since data from such analysis are useful in the risk assessment of emerging tick-borne diseases in a geographic area $[15,16]$.

The presence of $C$. burnetti in other tick species have been reported $[3,4]$. However, the importance of A. variegatum ticks in the Nigerian livestock industry in terms of damage to hides and skin, and their penchant to readily feed on man (especially the pastoralists) and increase their risk of exposure to diseases of public health significance $[17,18]$ influenced our study.

In this paper, we present the result of a survey in which the purpose was to use molecular methods and phylogenetics to identify and characterize the zoonotic pathogen $C$. burnetii in $A$. variegatum ticks collected from pastoralist herds in North central Nigeria.

\section{Materials and Methods}

Study area: The study was conducted in three Local Government Areas of Plateau State, Nigeria: Barkin

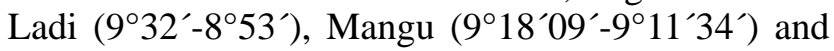
Jos-South $\left(9^{\circ} 47^{\prime}-8^{\circ} 51^{\prime}\right)$, and one local government area in Nasarawa State, Nigeria: Lafia $\left(9^{\circ} 28^{\prime}-\right.$ $\left.8^{\circ} 32^{\prime}\right)$, Figure-1. The study sites are positioned within the Northern Guinea savanna region; with plain lands and hills measuring up to $3000 \mathrm{ft}$ above sea level at some points, daily temperature range of $23^{\circ} \mathrm{C}-27^{\circ} \mathrm{C}$, and have a tropical climate and a moderate annual rainfall mean of about $1311.75 \mathrm{~cm}$ [19]. The area is home to some of the normadic Fulani pastoralists who are known to traverse from their origin in the semi-arid (Northern) parts of Nigeria to the sub-humid zones in the South in search of trade and pasture for their animals. Some of these normads are beginning to settle and live in sedentary households for easy access to regular markets in peri-urban areas where they trade their products [20]. It is from animals in several of such sedentary pastoralist communities that the tick samples were collected for the study.

Sample collection: A total of 40 A. variegatum tick samples were collected from the body of cattle on the basis of accessibility and convenience as a result of the ethno-religious conflicts inherent in the areas sampled. Each tick was carefully removed by grasping with a blunt curved forceps as close to the skin surface as possible and pulled upward with a steady even pressure, ensuring that the mouth parts were completely removed with the whole tick. Damaged ticks were removed and safely disposed while the intact ticks were cleaned by first sterilizing them in bleach and subsequently rinsing twice in distilled water and then preserved in $70 \%$ ethanol.

DNA extraction: The $A$. variegatum ticks were individually dissected with separate scalpel blades to remove the internal organs and DNA extracted using TriReagent (Sigma-Aldrich, Madrid, Spain) according to the manufacturer's instructions. DNA concentration was determined with a Nanodrop ND-1000 spectrophotometer (Wilmington, DE, USA), and then stored at $-20^{\circ} \mathrm{C}$ until used for analysis.

PCR amplification for $\mathbf{C}$. burnetii: The DNA samples from A. variegatum ticks were subjected to a nested PCR using oligonucleotide primers synthesized 
commercially by Sigma-Aldrich Biotechnology, L.P., Germany. Primary and secondary PCR amplifications were carried out with primer designates; Q5 (5'-GCG GGT GAT GGT ACC ACAACA- $3^{\prime}$ ) and Q3 (5'-GGC AAT CAC CAA TAA GGG CCG-3') ; Q6 (5'-TT GCT GGA ATG AAC CCC A-3') and Q4 (5'-TC AAG CTC CGC ACT CAT G-3') respectively. The primers amplifiy 501 and $325 \mathrm{bp}$ fragments of the $C$. burnetii $h t p B$ (heat shock protein B) gene of a $62 \mathrm{kDa}$ antigenic polypeptide [21].

The primary DNA amplification for the nested PCR was carried out in a reaction volume of $50 \mu 1$ containing $10 \mu \mathrm{l}$ of $10 \mathrm{X}$ Tfl buffer (Promega, Madison, WI, USA $), 1 \mu 1$ of $10 \mathrm{mM}$ dNTPs, $1 \mu \mathrm{l}(10 \mathrm{pmol})$ each of the primers (forward and reverse), $3 \mu 1$ of $25 \mathrm{mM}$ MgSO4, $1 \mu$ l of DNA sample (50 ng/ $\mu \mathrm{l}), 1 \mu \mathrm{l}$ of Tfl Polymerase (Promega, Madison, WI, USA) and $32 \mu 1$ nuclease-free water. The reaction mixture for the secondary nested PCR was the same as the first PCR except that $0.5 \mu \mathrm{l}$ of the PCR product (amplicons) from the first reaction was used as the DNA template, together with the Q6 and Q4 primers. Conditions for the reactions were an initial denaturation of $94^{\circ} \mathrm{C}$ for 3 minutes, 30 cycles of denaturation at $94^{\circ} \mathrm{C}$ for 1 minute, annealing at $56^{\circ} \mathrm{C}$ for 1 minute, and extension at $72^{\circ} \mathrm{C}$ for 1 minute, and a final extension of $72^{\circ} \mathrm{C}$ for 5 minutes. Conditions for the second PCR amplification are as described above with the exception of the annealing temperature which was set at $52^{\circ} \mathrm{C}$.

Amplification reactions were carried out in a thermocycler MyCycler 170-9711 (BioRad, Hercules, CA, USA). Amplicons from the reactions were visualized after electrophoresis on a $1 \%$ agarose gel stained with SYBR Safe DNA gel stain (Invitrogen, Eugene, OR, USA) and compared to a DNA molecular marker.

Cloning and sequencing of the htpB gene: Like in most molecular biology studies where large quantities of DNA molecule can be isolated in pure form for detailed molecular analysis, we ensured that the DNA isolated from A. variegatum ticks used in this study were actually that of $C$. burnetii by cloning it into the pGMET vector and purifying before sequencing.

Amplified products from the PCR reactions were purified using a Purelink PCR purification kit (Invitrogen, USA) according to the manufacturer's instructions, then ligated into pGEM ${ }^{\circledR}-\mathrm{T}$ Vector System I (Promega, Madison, USA) and transformed into JM109 high efficiency competent Escherichia coli cells according to the manufacturer's protocol. The transformed cells were subsequently plated on X-gal/ IPTG plates. The small, colourless positive transformants were selected and cultured in LB-Ampicillin medium at $37{ }^{\circ} \mathrm{C}$ overnight. Purification of the plasmid DNA was done with the QIAprep ${ }^{\circledR}$ Spin Miniprep kit (Qiagen, USA) while Proteus vulgaris II enzyme (Pvu II) kit (Fermentas $\left.{ }^{\circledR}\right)$ was used to digest the Plasmid DNA for evaluation of their size on $1 \%$ agarose prior to sequencing. For every PCR sample that was cloned, at least two clones from each purified plasmid were submitted for sequence confirmation in an automatic sequencer (3730 DNA analyzer, Applied Biosystem ${ }^{\circledR}$ ).

DNA sequence analysis: Comparison of our sequences with sequences previously deposited in the gene bank was done using the basic local alignment search tool (BLAST) at the NCBI database (http://www.ncbi.nlm. nih.gov/BLAST). The sequences were analyzed with the Clustal W Multiple Alignment feature of the BioEdit software. Phylogenetic analysis was done with sequence alignments obtained in this study and those by Reyes et al., [22] from Southern Nigeria and Spain. The GenBank accession numbers of the $C$. burnetii heat shock protein antigenic polypeptide $(h t p B)$ gene sequences used to construct the neigbour-joining tree [23] includes; JN871859, JN871850, JN871863 and EF547935, while Ehrlichia spp., (JF949769) was used as an outgroup. The distance matrix was calculated by use of Kimura-2 parameters, whilst 1000 bootstrap replicates were used to estimate the reliabilities of the branches on the tree. The output of the tree was constructed with the MEGA 4.1 program [24].

\section{Results}

Of the 40 partially fed $A$. variegatum ticks screened for $C$. burnetii using a specific nested PCR, we were able to detect the pathogen DNA in 10 ticks samples. This positive results from these $C$. burnetii-specific PCR assays provide molecular evidence for $C$. burnetii infection in the ticks, and with an infection rate of $25 \%$ for the areas under investigation. The ticks collected from the various areas had different levels of infection, with ticks from Barkin ladi and Lafia areas having the highest infection rate of $40 \%$ each.

BLAST search for the sequenced amplicons using the DDBJ/EMBL/ GenBank databases showed similarity of $99 \%-100 \%$ to the partial sequence of $C$. burnetii heat shock protein B gene $(h t p B)$ isolated from goat milk (GenBank accession numbers: EU888861EU888863) and Lions (EF547935). The sequences derived from our study are deposited in the GenBank under accession numbers JQ346185 - JQ346188. Phylogenetic analysis using neighbor-joining indicates the grouping of $C$. burnetii sequencesfrom our study areas with that collected from Oyo state, South-western Nigeria and Spain (Figure-2).

\section{Discussion}

Previous studies on the presence of C.burnetii in Nigeria were centered on the serological analysis of human sera [25]; fresh milk samples from cows; and suckling calves under different management systems $[26,5]$. In these studies, the prevalence rate of infection for the human sera was 3\%, while prevalence for both the milk and animal samples ranged from $24.3 \%$ $59.8 \%$.

However, Reye et al., [22] recently used PCR to establish the prevalence of $27 \%$ for C. burnetii 


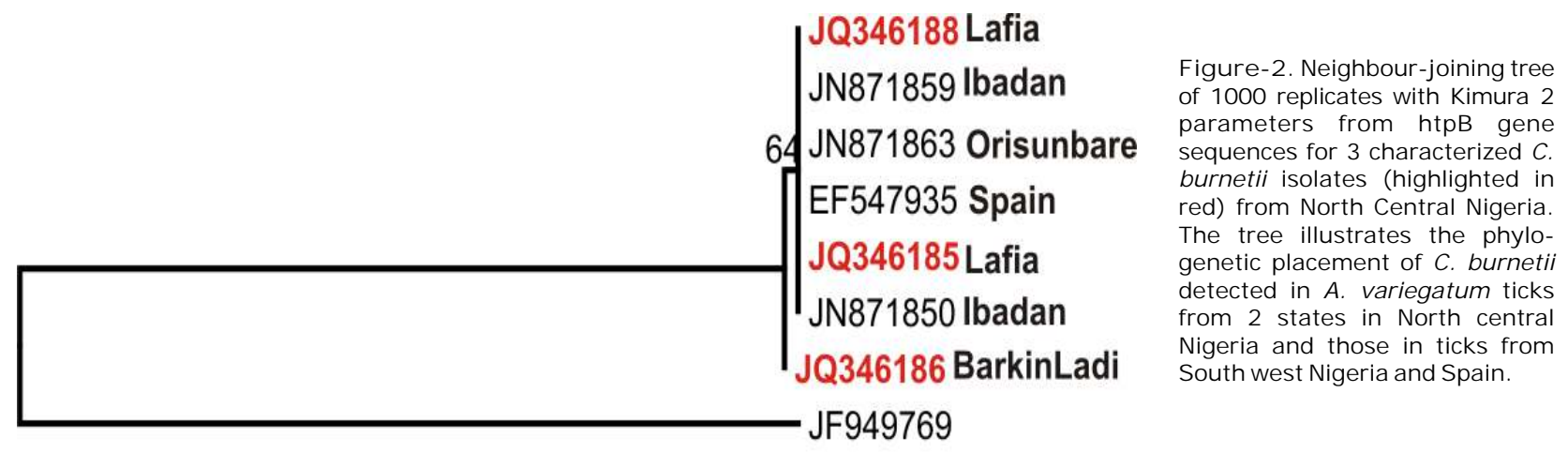

infection in ticks collected from the vegetation and livestock in Oyo state, South West, Nigeria. In this study, we sampled regions of the country that have a high concentration of pastoralists living in sedentary households and with high populations of ticks. Results from analyzing cloned fragments of the $C$. burnetii $h t p B$ gene obtained from feeding A. variegatum ticks, showed the detection of the organism in $25 \%$ of the 40 ticks analyzed. Sequences for the C. burnetii (htpB) gene detected in our samples had $99-100 \%$ identity to all other $C$. burnetii that have been described and were clustered together with those reported in the South western, Nigeria.

In Nigeria, $95 \%$ of livestock production is undertaken by the Fulani tribesmen. Their main system of production is pastoralism which involves unrestricted grazing and movement of ruminant livestock (mainly cattle) in response to variation in the availability of water, grazing pasture and the limitation imposed on cattle production by flies and livestock diseases [27]. This close and constant interaction between the pastoralists and their animals increases the chances of disease vectors such as A. variegatum attaching and transmitting any pathogen they harbor. Since A. variegatum have been involved in the transmission of other zoonotic pathogens [28], a prevalence of $25 \%$ C. burnetii in ticks collected from pastoralists-owned cattle in various localities in Nigeria increases the risk of $\mathrm{Q}$ fever infection and outbreak in this population.

\section{Conclusion}

This pilot study indicate that $A$. variegatum ticks are important sources of $C$. burnetii infection, and their presence in a particular locality may be used to assess the risk of human infection, especially in high risk groups like the pastoralists. Phylogenetic inferences indicates that the strain of $C$. burnetii found in the North central states of Plateau and Nasarawa were the same as those previously reported in the South western state of Oyo, we therefore propose that this is the only Coxiella spp. present in the country. For future risk assessments, it might be necessary to sample more ticks, increase the study areas of previously $C$. burnetii infected tick collection and possibly include samples from the pastoralists for analysis.

\section{Authors' contributions}

NIO and JdF conceived and designed the study, NIO, IGF, and RCG performed the experiments, NIO, OOO, IGF, and JdF analyzed the data, NIO, JdF, HMI, RISA, and $\mathrm{OOO}$ drafted and revised the manuscript. All authors read and approved the final manuscript.

\section{Acknowledgements}

Authors are grateful to the management of the National Veterinary Research Institute, Vom, Plateau State, Nigeria and the Instituto de Investigación en Recursos Cinegéticos, IREC-CSIC-UCLM-JCCM, Ciudad Real, Spain for their permission and financial support to conduct this study.

\section{Competing interests}

The authors declare that they have no competing interests.

\section{References}

1. Oyston, P.C.F. and Davies, C. (2011) Q fever: the neglected biothreat agent, J. Med.Microbiol. 60, 9-21.

2. Roest, H.I.J., Ruuls, R.C., Tilburg, J.J.H.C., NabuursFranssen, M.H., Klaassen, C.H.W., Vellema, P., van den Brom, R., Dercksen, D., Wouda, W., Spierenburg, M.A.H., van der Spek, A.N., Buijs, R., de Boer, A.G., Peter, Th.J., Willemsen, and van Zijderveld, F.G. (2011) Molecular epidemiology of Coxiella burnetii from ruminants in $\mathrm{Q}$ fever outbreak, the Netherlands. Emerg. Infect. Dis. 17: 668-675.

3. Nourollahi Fard, S.R., and Khalili, M. (2011) PCR-detection of Coxiella burnetii in ticks collected from Sheep and Goats in Southeast Iran. Iran J. Arthropod-Borne Dis, 5(1): 1-6.

4. Angelakis, E. and Raoult, D. (2010). Q fever, Vet Microbiol. 140: 297-309.

5. Adesiyun, A.A., Jagun, A.G., Kwaga, J.K., and Tekdek, L.B. (1985) Shedding of Coxiella burnetii in milk by Nigerian dairy and dual purposes cows, Int. J. Zoonoses, 12:1-5.

6. Honarmand, H. (2012) Q Fever: An Old but Still a Poorly Understood Disease, Interdiscipl. Persp. Infect. Dis. doi:10.1155/2012/131932.

7. Marrie, T.J. (2010) "Q fever pneumonia," Infect. Dis. Clin. NorthAmerica, 24(1):27-41.

8. Sprong, H., Tijsse-Klasen, E., Langelaar, M., De Bruin, A., Fonville, M., Gassner, F., Takken, W., Van Wieren, S., Nijhof, A., Jongejan, F., Maassen, C.B.M., Scholte, E.-J., Hovius, J.W., Hovius, E. K., Spitalska, E., and Van Duynhoven, Y.T. (2012) Prevalence of Coxiella burnetii in 
Ticks After a Large Outbreak of Q Fever, Zoonoses Public Health, 59: 69-75.

9. Machado-Ferreira, E., Piesman, J., Zeidner, N.S. and Soares, C.A.G. (2009) Francisella-like endosymbiont DNA and Francisella tularensis virulence-related genes in Brazilian ticks (Acari, Ixodidae). J. Med. Entomol, 46:369-374.

10. Klyachko, O., Stein, B.D., Grindle, N., Clay, K., and Fuqua, C. (2007) Localization and visualization of a Coxiella-type symbiont within the lone star tick, Amblyomma americanum, Appl. Environ. Microbiol, 73: 6584-6594.

11. Machado-Ferreira, E., Dietrich, G., Hojgaard, A., Levin, M., Piesman, J., Zeidner, N.S., and Soares, C.A.G. (2011) Coxiella symbionts in the Cayenne tick Amblyomma cajennense. Microb. Ecol, 62:134-142.

12. Natala, A.J., Okubanjo, O.O., Ulayi, B.M., Owolabi, Y.N., Jatau, I.D. and Yusuf, K.H. (2009) Ectoparasites of domestic animals in Northern Nigeria. J. Animal and Plant Sci, 3: 238242.

13. Ogo, N. I., Fernández de Mera, G.I., Galindo, R. C., Okubanjo, O.O., Inuwa, H.M., Agbede, R.I.S., Torina, A., Alongi, A., Vicente, J., Gortázar, C. and de la Fuente, J. (2012) Molecular identification of tick-borne pathogens in Nigerian ticks. Vet. Parasitol, 187: 572-577.

14. Bayer, W. and Maina, J.A. (1984) Seasonal pattern of tick load in Bunaji cattle in the subhumid zone of Nigeria. Vet. Parasitol, 15:301-307.

15. Halos, L., Bord, S., Cotte, V., Gasqui, P., Abrial, D., Barnouin, J., Boulouis, H-J., Vayssier-Taussat, M., and Vourch, G. (2010) Ecological factors characterizing the prevalence of bacterial tick-borne pathogens in Ixodes ricinus ticks in pastures and woodlands. Appl. Environ. Microbiol, 4413-4420.

16. Satta, G., Chisu, V., Cabras, P., Fois, F., and Masala, G (2011) Pathogens and symbionts in ticks: a survey on tick species distribution and presence of tick transmitted microorganisms in Sardinia, Italy. J. Med. Microbiol, 60: 63-68.

17. Anderson, J.F. and Magnarelli, L.A. (2008) Biology of ticks. Infect. Dis. Clin. N. Am. 22: 195-215.

18. Dantas-Torres, F., Chomel, B.B., and Otranto, D. (2012)
Ticks and tick-borne diseases: a One Health perspective. Trends Parasitol. Xx: 1-10. doi:10.1016/j.pt.2012.07.003.

19. Anonymous (1925). Reports of the Veterinary Department of Nigeria.

20. Sodiya, C.I., Adedire, M.O. and Lawal-Adebowale, O.A. (2009) Land holding rights of Fulani pastoralists and its effects on their agropastoral production system in Ogun State, Nigeria. Tropicultura, 27: 65-69.

21. Vodkin, M.H. and Williams, J.C. (1988) A heat shock operon in Coxiella burnetii produces a major antigen homologous to a protein in both bacteria and Escherichia coli, J. Bacteriol. 170:1227-1234.

22. Reye A. L, Arinola G.O., Hübschen J.M., and Muller C.P. (2012) Pathogen Prevalence in Ticks Collected from the Vegetation and Livestock in Nigeria, Appl. Environ. Microbiol. 78 (8): 2562-2568.

23. Saitou, N. and Nei, M. (1987) The neighbor-joining method: a new method for reconstructing phylogenetic trees. Mol. Biol. and Evol. 4: 406-425.

24. Tamura, K., Dudley, J., Nei, M., and Kumar, S. (2007) MEGA4: Molecular evolutionary genetics analysis (MEGA) software version 4.1. Mol. Biol. and Evol, 24: 1596-1599.

25. Sixl, W., Rosegger, H., Schneeweiss, H., Withalm, H., and Schuhmann, G. (1987) Serological investigations in Nigeria for anthropozoonoses in human sera: brucellosis, echinococcosis, toxoplasmosis, chlamydial diseases, listeriosis, rickettsiosis (Coxiella burneti and Rickettsia conorii). J. Hyg. Epidemiol. Microbiol. Immunol, 31: 493-5.

26. Adesiyun, A.A., Jagun, A.G., and Tekdek, L.B. (1984) Coxiella burnetii antibodies in some Nigerian dairy cows and their suckling calves, Int. J. Zoonoses. 11(2):155-60.

27. Fabusoro, E. (2007) Key Issues in Livelihoods Security of Migrant Fulani Pastoralists: Empirical Evidence from Southwest Nigeria. http://ecas2007.aegiseu.org/ commence/ user/view_file_forall.php?fileid=931. Accesssed on 18-122012.

28. Sidoti, E. and Tringali, G. (2009) Ehrlichioses and Anaplasmoses: (re)emerging tickborne. J. Prev. Med. Hyg. 50:9-18. 